\title{
English Reading Proficiency of Engineering Undergraduates in Malaysia: Implications on Professional Training and Career Development
}

\author{
Abdul Rashid Mohamed ${ }^{1}$, Shaik Abdul Malik Mohamed Ismail ${ }^{2}$, Hui Min Low ${ }^{3^{*}}$ \\ ${ }^{1}$ Albukhary International University \\ ${ }^{2}$ Universiti Sains Malaysia \\ ${ }^{3}$ School of Educational Studies, Universiti Sains Malaysia, Penang, Minden 11800, Malaysia \\ E-mail: lowhm@usm.my
}

\begin{abstract}
This paper reports the English reading proficiency of a sample of engineering undergraduates in a public university of Malaysia. A standardized online reading comprehension assessment, called Reading Evaluation and Decoding System (READS) was administered with 189 first year engineering students during their enrolment into six different engineering faculties in the university. The results showed that only $7.9 \%$ of the engineering students were able to perform above secondary school level of English reading comprehension proficiency. Specifically, the students were found to perform poorer in questions related to critical thinking than those related to literal comprehension and reorganization. The implications of the findings on the English language education and the professional training of future engineers in Malaysia were discussed.
\end{abstract}

Keywords: english reading proficiency, engineering undergraduate, Malaysia, english language education

\section{Introduction}

It is the norm that the engineering industry is characterized by extreme competitiveness, innovation and widespread use of English ${ }^{[1]}$. To meet with the demands of globalization, it is important for engineers and prospective engineers to equip with various industrial skills such as proficiency in English; other than their hard - core technical skills and knowledge in engineering sciences ${ }^{[2]}$. In a study on engineering employability skills required by employers in Asia, researchers compared the findings from different studies in Malaysia, Japan, Singapore and Hong Kong and they found that the employers in Malaysia and Japan both pointed to communication competency as the first employability skill that they expected from their potential employees, including the competency to communicate in English ${ }^{[3]}$.

There are at least two main reasons that today's engineers and prospective engineers need to equip with a good proficiency of English language. First, the world is now becoming increasingly borderless due to the rapid advancement of information technology. Most often, English is used as the lingual franca in different levels of work communication. As recorded by Malaysian researchers in a study with 65 engineers from 10 multinational chemical companies in Malaysia, they found that $41 \%$ of communication in the company is carried out in English. Hence, it is important that engineers and prospective engineers are able to communicate with their work counterparts and collaborators in English ${ }^{[4]}$. Second, many engineers will eventually being promoted from their original positions to become managers and directors of company ${ }^{[2]}$. In such instances, the ability to communicate in English is becoming even more important during customer visits and relationship building ${ }^{[1]}$. Besides that, other business activities that involve the use of English include global conference calls, product presentation, and customer or partner negotiation ${ }^{[5]}$.

English is required in the everyday work practice of engineers. In a study with process integration engineers in Taiwan, the researchers found that over $60 \%$ of their respondents reported that they required the skills to read and write in English on a daily basis. Specifically, $84.3 \%$ of the engineers were reading English emails on a daily basis, while $52.9 \%$ were reading written instructions and advice in English on a daily basis ${ }^{[1]}$. Hence, reading in English was one of the basis English language skills that engineers are expected to have. In a study with 189 novice engineers in Thailand, the Thai researchers also added the perspective that engineers need the abilities to read engineering - related articles, reports, and 
minutes which are often being written in English ${ }^{[6]}$.

Despite the importance of English reading skills, such skills were often not routinely assessed or explicitly taught in engineering training programs. English reading skills are often being neglected in the higher education context. In an ESL country such as Malaysia, available studies showed that many university students do not read in English ${ }^{[7,8]}$. In a survey with 150 students in a public university in Malaysia, the researchers found that only $27.3 \%$ of the students prefer to read in English. The others prefer to read printed materials in their respective first languages (63.3\% in Malay language, $14.1 \%$ in Mandarin, and $4.0 \%$ in Tamil) ${ }^{[7]}$. Similarly, in a study which involved 119 students in a Malaysian Polytechnic, the researchers found that only $10.1 \%$ of the students prefer to read in English. The others reported preference to read in their respective first languages. The lack of motivation to read in English is worrisome as this could negatively impact on the students' acquisition of proficiency and strategy to read in English $^{[8]}$.

In a study on the reading strategies of undergraduate students in Malaysia, it was found that the Malaysian undergraduate students predominantly only rely on the low level strategy, such as literal comprehension and translation strategy when they perform English reading ${ }^{[9]}$. Many students reported that they rarely or never read analytically or critically, i.e., use contextual or background information to interpret the text context. Such reading practice among the Malaysian students is arguably causing difficulties in the students to respond appropriately to academic texts when they are in the university ${ }^{[10]}$.

At the university level, the students are required to have the critical literacy abilities to meet the academic demands in the university ${ }^{[10]}$. However, available studies with the university students in Malaysia revealed that many university students are unable to perform critical and constructive reading, in which they are unable to locate information from a reading text, and to identify the links between paragraph to comprehend a text ${ }^{[10]}$. Such phenomenon is particularly obvious when the students are required to read in English ${ }^{[9]}$. The reduced proficiency to read in English would inevitably affect the students' abilities to gain knowledge from English resource materials. This would ultimately affect the students' performance in certain content subject areas, particularly in the area of engineering which many resource materials are only mainly available in English.

Reading comprehension is an important aspect of reading proficiency. Reading comprehension performances are typically being described using taxonomies of reading comprehension such as the Bloom taxonomy. Consequently, the reading skills are typically categorized hierarchically, from the basic literal comprehension to the advance inferential comprehension. In large, there are three differentiable levels of reading comprehension, namely literal comprehension, reorganization, and inferential comprehension. These three levels of reading comprehension coincide with the Revised Bloom's Taxonomy of Educational Objectives ${ }^{[11]}$. 'Literal comprehension' refers to the identification of letters, phrases, sentences, main idea and supporting details from the reading text. 'Reorganization' refers to the translation of information and the identification of cause and effect relationships from the reading text, while 'inferential comprehension' refers to the ability to relate to the details and main ideas in the reading text based on one own personal experience ${ }^{[1]}$. Inferential comprehension is regarded as the advance level of reading comprehension in which the reader is able to draw conclusion, make inference, and identify information which is not explicitly stated in the reading text.

Past studies provided insights that many tertiary level students in Malaysia are lacking the ability to perform inferential comprehension ${ }^{[9]}$. However, the majority of available studies were surveys and interviews which the conclusion was drawn from the subjective measures of reading strategies used by the students. To the best of our knowledge, no study known had formally assessed the reading comprehension level of the tertiary level students in their studies, particularly with students in the area of engineering. Therefore, the aim of this study was to investigate the reading comprehension proficiency of tertiary level engineering students in Malaysia. Firstly, the study hoped to obtain an objective measure of their levels of reading comprehension based on a standardized reading comprehension assessment developed and normed locally. Secondly, the study hoped to measure their abilities to perform literal comprehension, reorganization and inferential comprehension. Thirdly, the study also hoped to identify factors which impact on their reading comprehension proficiencies.

\section{Methodology}

\subsection{Sampling}

The larger study involved a cohort sampling of the first - year undergraduate students when they enrolled in a public university in Malaysia. The announcement of the study was made to all students during the orientation week, and they were encouraged to participant. For this article, the reporting and analysis only focused on the students from the 
engineering faculties in the university. From 613 students who enrolled in the engineering faculties, 189 students participated in this study, representing $30.8 \%$ of the total population of first - year undergraduate students in the engineering faculties. The students consisted of those from schools of Aerospace Engineering $(n=13)$, Chemical Engineering $(n=79)$, Civil Engineering $(\mathrm{n}=5)$, Electrical and Electronic Engineering $(\mathrm{n}=18)$, Materials and Mineral Resources Engineering $(\mathrm{n}$ $=57)$, and Mechanical Engineering $(\mathrm{n}=17)$.

\subsection{Procedure}

Upon the research approval obtained from the university administrator, a standardized online reading comprehension assessment, called Reading Evaluation and Decoding System (READS) was conducted with all the first - year students during their enrolment into their university. The students received notice to complete the assessment during the university orientation program.

\subsection{Instrument}

Reading Evaluation and Decoding System (READS) was an online system initially developed to assess the proficiency of reading comprehension among the secondary-school students in Malaysia ${ }^{[12,13]}$. This assessment contains five reading passages and 60 multiple choice questions which were developed based on the revised Barrett's Taxonomy of Reading Comprehension skill levels: (1) literal comprehension (ability to recognize information stated explicitly in the text), (2) reorganization (ability to analyze, synthesize, and organize information stated explicitly in the text), (3) inferential comprehension (ability to make inference and hypothesis based on explicit information available in the text and one's own personal experience $)^{[14]}$. The prototype of READS was tested with 1339 Secondary 1 to 5 Malaysian school students ${ }^{[14]}$. Following that, a reading matrix (Bands 1 to 6 ) with the descriptors of reading abilities were developed based on the results gathered from the preliminary study ${ }^{[14]}$. This online assessment system was later normed with 3567 Malaysian secondary school students from various school types and social backgrounds ${ }^{[14]}$. This is the first time this online assessment system was used with an university population. Table 1 summarizes the performance bands used for the scoring of READS ${ }^{[12,13]}$.

Table 1. Performance bands used for the scoring of READS

\begin{tabular}{ccccccc}
\hline & Band 1 & Band 2 & Band 3 & Band 4 & Band 5 & Band 6 \\
\hline $\begin{array}{c}\text { Scores } \\
\text { Projected }\end{array}$ & $0-6$ & $7-18$ & $19-29$ & $30-41$ & $54-60$ \\
$\begin{array}{c}\text { Reading } \\
\begin{array}{c}\text { Age } \\
\text { (years old) }\end{array}\end{array}$ & 1 & Secondary & Secondary & Secondary & Secondary \\
\hline
\end{tabular}

\section{Results}

\subsection{Demographic data}

The demographic data of the engineering students are summarized in Table 2. All the students were between 19 and 25 years of age. There are slightly more female (57.1\%) than male students $(42.9 \%)$. The data also indicated that almost two third the participating students were from School of Chemical Engineering (41.8\%) and School of Materials and Mineral Resources Engineering (30.2\%). In terms of their origins, about half of the students were from the Northern region of Peninsular Malaysia (56.5\%), i.e., 22.2\% were from Penang, 19.0\% were from Perak, and 15.3\% were from Kedah. In Malaysia, different states had rather different socio - cultural and conomic representations. Hometown was used as an indicator of such differences. In addition, as shown in Table 2, 76.2\% of these students were from families with monthly income less than RM4500, considered as the bottom $40 \%$ income group in Malaysia. 
Table 2. Demographic data of the engineering students $(N=189)$

\begin{tabular}{|c|c|c|c|}
\hline & & Frequency & Percent \\
\hline \multirow[t]{6}{*}{ Schools } & School of Chemical Engineering & 79 & 41.8 \\
\hline & School of Materials and Mineral Resources Engineering & 57 & 30.2 \\
\hline & School of Electrical and Electronic Engineering & 18 & 9.5 \\
\hline & School of Mechanical Engineering & 17 & 9.0 \\
\hline & School of Aerospace Engineering & 13 & 6.9 \\
\hline & School of Civil Engineering & 5 & 2.6 \\
\hline \multirow[t]{2}{*}{ Gender } & Female & 108 & 57.1 \\
\hline & Male & 81 & 42.9 \\
\hline Age & $19-25$ years old & 189 & 100 \\
\hline \multirow[t]{15}{*}{ Hometown } & Pulau Pinang & 42 & 22.2 \\
\hline & Perak & 36 & 19.0 \\
\hline & Selangor & 30 & 15.9 \\
\hline & Kedah & 29 & 15.3 \\
\hline & Kelantan & 10 & 5.3 \\
\hline & Pahang & 10 & 5.3 \\
\hline & Negeri Sembilan & 7 & 3.7 \\
\hline & Johor & 5 & 2.6 \\
\hline & Melaka & 5 & 2.6 \\
\hline & WP Kuala Lumpur & 5 & 2.6 \\
\hline & Terengganu & 4 & 2.1 \\
\hline & Sarawak & 3 & 1.6 \\
\hline & Perlis & 1 & 0.5 \\
\hline & Sabah & 1 & 0.5 \\
\hline & WP Putrajaya & 1 & 0.5 \\
\hline \multirow[t]{4}{*}{ Ethnicity } & Malay & 120 & 63.5 \\
\hline & Chinese & 38 & 20.1 \\
\hline & Indian & 26 & 13.8 \\
\hline & Others & 5 & 2.7 \\
\hline \multirow[t]{5}{*}{ Family monthly income } & RM1500 and below (bottom $40 \%$ income group) & 65 & 34.4 \\
\hline & RM1501 - RM3000 (bottom 40\% income group) & 56 & 29.6 \\
\hline & RM3001 - RM4500 (bottom 40\% income group) & 23 & 12.2 \\
\hline & RM4501 - RM6000(middle 40\% income group) & 22 & 11.6 \\
\hline & RM6001 and above (middle $40 \%$ to top $20 \%$ income group) & 23 & 12.2 \\
\hline
\end{tabular}

${ }^{*}$ The income group classification is based on Report of Household Income and Basic Amenities Survey 2016 ${ }^{[15]}$

\subsection{Previous academic and English results}

The students' CGPA in their pre - university standard examinations were obtained to reflect their academic abilities; while their English results in two national examinations, namely SPM and MUET were obtained to reflect their previous English performances. One - tailed Pearson correlation analysis indicated that there was no significant correlation between their overall academic results (i.e. CGPA scores) and their previous SPM English grades, $r(189)=.121, p=.09$ and MUET results, $\mathrm{r}(189)=.110, \mathrm{p}=.131$. The correlation between their SPM English grades and MUET results were moderate, $\mathrm{r}(189)=.543, \mathrm{p}<.05$. As revealed in Table $3,95.5 \%$ of the students obtained more than 3.00 for their CGPA during preuniversity standard examinations. This indicated that the students were high - performing in their academic achievements. As for the previous English results, 51.3\% of the students obtained Band 3 from MUET (the highest band = Band 6). Comparatively, their SPM English grades were more diverse, ranged between A+ and C. 
Table 3. Crosstabulation of previous academic and English results

\begin{tabular}{|c|c|c|c|c|c|c|c|c|}
\hline & & & & & CGPA & & & \\
\hline MUET & & & $2.50-2.75$ & $3.01-3.25$ & $3.26-3.50$ & $3.52-3.75$ & Above 3.75 & Total \\
\hline \multirow[t]{6}{*}{ Band 2} & $\begin{array}{l}\text { English Grade } \\
\text { (SPM) }\end{array}$ & $\mathrm{C}$ & & 0 & 1 & 0 & 1 & 2 \\
\hline & & $\mathrm{C}+$ & & 1 & 0 & 3 & 0 & 4 \\
\hline & & B & & 0 & 0 & 0 & 2 & 2 \\
\hline & & $\mathrm{B}+$ & & 0 & 0 & 1 & 2 & 3 \\
\hline & & A & & 0 & 0 & 0 & 1 & 1 \\
\hline & Sub - total & & & 1 & 1 & 4 & 6 & $\begin{array}{c}12 \\
(6.3 \%)\end{array}$ \\
\hline \multirow[t]{7}{*}{ Band 3} & $\begin{array}{l}\text { English Grade } \\
\text { (SPM) }\end{array}$ & $\mathrm{C}$ & & 0 & 0 & 1 & 5 & 6 \\
\hline & & $\mathrm{C}+$ & & 1 & 2 & 5 & 1 & 9 \\
\hline & & B & & 3 & 3 & 2 & 7 & 15 \\
\hline & & $\mathrm{B}+$ & & 4 & 2 & 8 & 17 & 31 \\
\hline & & A- & & 2 & 2 & 2 & 13 & 19 \\
\hline & & A & & 2 & 1 & 5 & 9 & 17 \\
\hline & Sub - total & & & 12 & 10 & 23 & 52 & $\begin{array}{c}97 \\
(51.3 \%)\end{array}$ \\
\hline \multirow[t]{6}{*}{ Band 4} & $\begin{array}{l}\text { English Grade } \\
\text { (SPM) }\end{array}$ & B & 0 & 0 & 1 & 0 & 3 & 4 \\
\hline & & $\mathrm{B}+$ & 0 & 1 & 2 & 1 & 2 & 6 \\
\hline & & A- & 0 & 1 & 4 & 2 & 11 & 18 \\
\hline & & A & 1 & 1 & 6 & 7 & 23 & 38 \\
\hline & & $\mathrm{A}+$ & 0 & 0 & 0 & 1 & 4 & 5 \\
\hline & Sub - total & & 1 & 3 & 13 & 11 & 43 & $\begin{array}{c}71 \\
(37.6 \%)\end{array}$ \\
\hline \multirow[t]{6}{*}{ Band 5} & $\begin{array}{l}\text { English Grade } \\
\text { (SPM) }\end{array}$ & $\mathrm{B}+$ & & & & & 2 & 2 \\
\hline & & A- & & & & & 2 & 2 \\
\hline & & A & & & & & 2 & 2 \\
\hline & & $\mathrm{A}+$ & & & & & 3 & 3 \\
\hline & Sub - total & & & & & & 9 & $\begin{array}{c}9 \\
(4.8 \%)\end{array}$ \\
\hline & Total & & $\begin{array}{c}1 \\
(0.5 \%)\end{array}$ & $\begin{array}{c}16 \\
(8.5 \%)\end{array}$ & $\begin{array}{c}24 \\
(12.7 \%)\end{array}$ & $\begin{array}{c}38 \\
(20.1 \%)\end{array}$ & $\begin{array}{c}110 \\
(58.2 \%)\end{array}$ & 189 \\
\hline
\end{tabular}

\subsection{READS' results}

Figure 1 shows the performance bands obtained by the engineering students in the READS' online assessment. ANOVA analysis indicated that there were no significant differences between the students across different engineering programs, $\mathrm{F}(8,180)=1.226, \mathrm{p}=.286$. Overall, near two third of the students obtained Band $5(77.2 \%)$, which indicated that the students were equipped with a Form 5 standard of reading competency (Reading age $=17$ years old). Besides that, there were only $7.9 \%$ of them with above Form 5 standard of reading competency; and as many as $14.8 \%$ of others actually had below Form 5 standard of reading competency. The overall reading competency level portrayed by the students suggested that more than $90 \%$ of them might not be ready to read their academic resource materials in English with ease. 


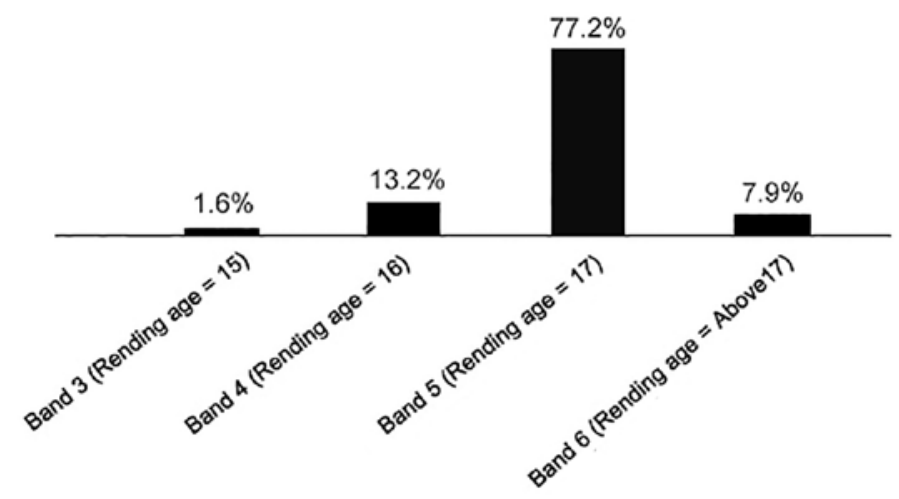

Figure 1. Performance bands of READS obtained by the engineering students

As previously mentioned, the READS' assessment contained three levels of questions, namely literal comprehension (Level 1), reorganization (Level 2), inferential comprehension (Level 3). The scores that the students obtained in each level of questions were converted into percentage scores. Figure 2 shows the percentage scores of the engineering students in three levels of reading comprehension. The majority of students were able to obtain above $90.0 \%$ accuracy for questions related to literal comprehension $(n=87,46.0 \%)$. In comparison, less students were able to obtain this level of accuracy for questions related to reorganization $(n=36,19.0 \%)$ and inferential comprehension $(n=10,5.3 \%)$. Specifically, the abilities of the students to answer questions on inferential comprehension were significantly lower and more diverse. As represented by the striped bars in Figure 2, the majority of students only scored $79.9 \%$ and below for questions related to inferential comprehension $(n=143,75.7 \%)$. The findings portrayed the reduced abilities of the engineering students to perform inferential comprehension.

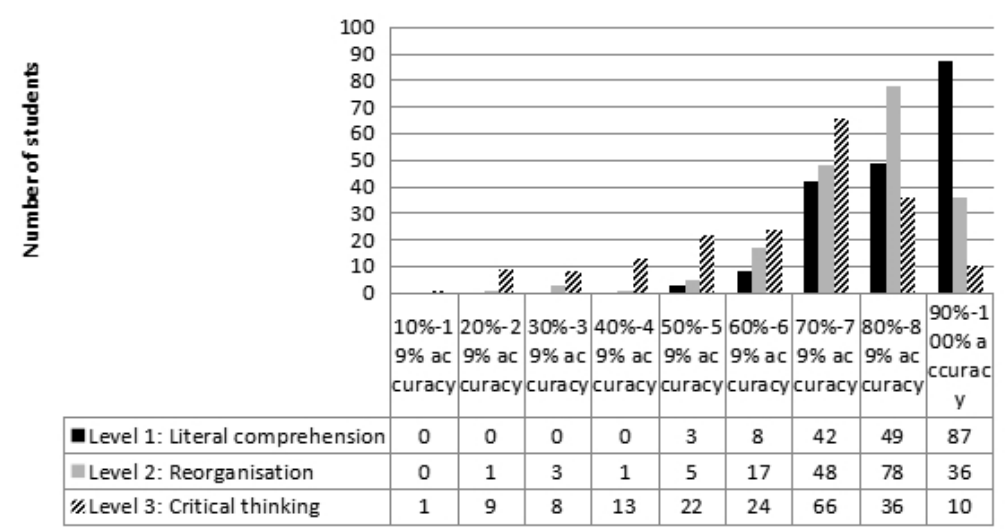

Figure 2. Percentage scores of the students in three levels of reading comprehension

\subsection{Predictors of reading comprehension}

Table 4 shows the results of Pearson one - tailed correlation analyses. Hometown, ethnicity, previous English results (SPM and MUET results) and family income were found to correlate significant with the READS' total scores. The correlation findings for each level of reading comprehension were slightly different, denoting different types of variables were impacting on different levels of reading comprehension. 
Table 4. Correlations of demographic variables and reading comprehension scores

\begin{tabular}{|c|c|c|c|c|c|c|c|c|}
\hline & Program & Gender & Hometown & Ethnicity & CGPA & MUET & SPM English & $\begin{array}{l}\text { Family } \\
\text { income }\end{array}$ \\
\hline Total scores & - & - & $.124^{*}$ & $-.189^{* * *}$ & - & $.464^{* * *}$ & $.445^{* *}$ & $.126^{*}$ \\
\hline $\begin{array}{c}\text { Literal } \\
\text { comprehension }\end{array}$ & $-.158^{*}$ & - & - & - & - & $.171^{* *}$ & $.304^{* *}$ & $.122^{*}$ \\
\hline Reorganization & - & - & - & $-.143^{*}$ & - & $.367^{* *}$ & $.336^{* *}$ & $.139^{*}$ \\
\hline $\begin{array}{l}\text { Inferential } \\
\text { comprehension }\end{array}$ & - & - & $.195^{* *}$ & $-.218^{* *}$ & - & $.409^{* * *}$ & $.365^{* *}$ & - \\
\hline
\end{tabular}

"** Correlation is significant at the 0.01 level $(1$ - tailed)

"Correlation is significant at the 0.05 level ( 1 - tailed)

Results of multiple regression analyses provided further insights that the previous English results (MUET and SPM English) were the significant predictors for the READS' total scores, $\mathrm{R} 2=.275, \mathrm{~F}(5,183)=13.882, \mathrm{p}<.001$. The similar set of predictors were found for the students' performance in reorganization, $R 2=.165, F(4,184)=9.096, p<.001$. On the other hand, program and SPM English result were the significant predictors for the students' performance in literal comprehension, $\mathrm{R} 2=.118, \mathrm{~F}(4,184)=6.164, \mathrm{p}<.001$; while hometown and MUET result were the significant predictor for the students' performance in literal comprehension, $\mathrm{R} 2=.211, \mathrm{~F}(4,184)=12.292, \mathrm{p}<.001$.

Table 5. Multiple regression analyses of demographic variables and reading comprehension scores

\begin{tabular}{|c|c|c|c|c|c|c|c|c|}
\hline & \multicolumn{2}{|c|}{ Total score } & \multicolumn{2}{|c|}{ Literal comprehension } & \multicolumn{2}{|c|}{ Reorganization } & \multicolumn{2}{|c|}{ Critical Thinking } \\
\hline & $\beta$ & $\mathrm{P}$ & $\beta$ & $\mathrm{P}$ & $\beta$ & $\mathrm{P}$ & $\beta$ & $\mathrm{P}$ \\
\hline Program & & & -.025 & .047 & & & & \\
\hline Hometown & - & - & & & & & .086 & .007 \\
\hline Ethnicity & - & - & & & - & - & - & - \\
\hline MUET & 2.620 & .000 & - & - & .464 & .002 & .980 & .000 \\
\hline SPM English & .994 & .001 & .192 & .001 & .151 & .025 & - & - \\
\hline Family Income & - & - & - & - & - & - & & \\
\hline
\end{tabular}

\section{Discussion}

This study was conducted to investigate the English reading comprehension proficiency of tertiary level engineering students $(\mathrm{N}=189)$ in a public university in Malaysia. A locally developed and normed standardized online reading comprehension assessment called Reading Evaluation and Decoding System (READS) was used to objectively measure the students' reading comprehension proficiency ${ }^{[12]}$. The results indicated that the majority of the students were performing at Band $5(77.2 \%)$, reflecting merely a Form 5 level of reading comprehension. Overall, only $7.9 \%$ were performing at Band 6, reflecting above Form 5 level of reading comprehension.

In large, the findings implied the scenario that only less than $10 \%$ of these future engineers are equipped with the required competencies to interpret English reading materials at the tertiary education level. This is a condition that should be taken seriously by the relevant educational authorities. Past research had indicated that the need for English competence increases in tandem with a career advancement in engineering ${ }^{[1]}$. Considering the industry competitiveness of graduate recruitment, higher education authorities in Malaysia should look seriously into the development of English competencies among the local engineering undergraduate students, as part of their core employability skills development ${ }^{[2]}$.

Next, the students' performance in questions on literal comprehension, reorganization and inferential comprehension were analyzed. The results showed that the engineering students were more capable to answer literal comprehension questions (46.0\% scored above $90 \%$ accuracy) and reorganization questions (19.0\% scored above $90 \%$ accuracy) than questions on inferential comprehension. Only $5.3 \%$ of the students were able to score above $90 \%$ accuracy for questions on inferential comprehension. The findings revealed not many of these engineering students had the abilities to perform critical thinking when they respond to English reading text. The findings are consistent with past findings that Malaysian undergraduate students tended to use avoidance and other compensatory strategies while reading in English. Whenever the students come across a part of text they cannot understand, they tend to disregard $\mathrm{it}^{[9]}$. In comparison, cognitive strategies such as analyzing and note taking are not commonly practised by these students, even though these strategies are useful to aid the construction of meanings from the text.

Besides that, the reading comprehension proficiencies of the students were found to be largely influenced by their overall English competencies. In other words, students with better English proficiency as indicated by their English 
results in the two previous national examinations, namely SPM English and MUET, were performing better in the English reading comprehension than the opposite. Even though the effect of previous English proficiency on English reading comprehension is a naturally expected outcome; this finding had two important implications. First, it emphasizes the importance of having a good foundation of English proficiency. Good English proficiency acquired by the students from secondary school would continue to benefit them in their academic literacy activities in the university. Second, it also highlighted the importance of adopting a holistic remedial approach for those students who are experiencing low English proficiency. It is important for the English curricular developer and instructor to realize that the skills of reading, writing, listening and speaking are mutually supporting one and another. Neither skill should be neglected in the English remediation program for students with low English proficiency, including those engineering undergraduate students in this study.

To move forward, it is pertinent that Malaysian university authorities should encourage more academic activities which are conducted in English. In a study with the pre - university students and final - year students in a Malaysian engineering - based university, the researchers found that extended exposure to English in the engineering undergraduate programs did contribute to enhance the undergraduate students' self-efficacy in English ${ }^{[16]}$. To prepare Malaysian engineering students for the global job market, it is important that English is continue being used as a medium of instruction in the local engineering courses as a way to enhance the graduates' employability skills. In addition to encouraging group discussions and presentations in English ${ }^{[16]}$, engineering undergraduate students should be given more suggested readings in English and being directed to participate in more English online courses. Such efforts are necessary as past research had indicated that Malaysian engineering undergraduates do not have adequate knowledge of technical terms in English ${ }^{[17]}$. The lack of technical vocabulary knowledge in English is undoubtedly linked to reduced reading habits in English, implying the importance of institutional efforts in encouraging more initiatives of reading and professional learning in English.

\section{Conclusion}

Given that English is an international language, the findings call for the needs to improve the English reading proficiency of engineering undergraduate students in Malaysia. The abilities to read in English is important for these students to access to the latest professional knowledge and to perform critical analysis of the technical knowledge accessed by them. This would substantially increase their competitiveness and employability when they graduate. From this study, it is apparent that as a group, the English reading proficiency of these engineering undergraduate students is not high. This calls for the needs to better equip these future engineers with better critical literacy abilities in English as part of a more holistic professional training.

\section{References}

[1] Spence P, Liu GZ. Engineering English and the high - tech industry: A case study of an English needs analysis of process integration engineers at a semiconductor manufacturing company in Taiwan. English for Specific Purposes. 2013; 32(2): 97-109.

[2] Johari MM, Abdullah AA, Osman MR, Sapuan MS, Mariun N, Jaafar MS, Ghazali AH, Omar H, Rosnah MY. A new engineering education model for Malaysia. International Journal of Engineering Education. 2002; 18(1): 8-16.

[3] Zaharim, A., Yusoff, Y., Omar, M., Z., Mohamed, A., Muhamad, N. Engineering employability skills required by employers in Asia. Proceedings of the 6th WSEAS international conference on Engineering education. 2009; 195 $-201$.

[4] Kassim H, Ali F. English communicative events and skills needed at the workplace: Feedback from the industry. English for Specific Purposes. 2010; 29(3): 168-182.

[5] Sarudin I, Zainab MN, Zubairi, AM, Tunku Ahmad TB, Nordin MS. Needs assessment of workplace English and Malaysian graduates' English language competency. World Applied Sciences Journal. 2013; 21: 88-94.

[6] Rajprasit K, Pratoomrat P, Wang T. Perceptions and problems of English language and communication abilities: A final check on Thai engineering undergraduates. English Language Teaching. 2015; 8(3): 111-120.

[7] Chee, V., Pandian, A. University students' interaction with print and technology. International Journal of Arts \& Sciences. 2012; 5(5): 377-385.

[8] Annamalai S, Muniandy B. Reading habit and attitude among Malaysian Polytechnic students. International Online Journal of Educational Sciences. 2013; 5(1): 32-41. 
[9] Nambiar RM. Enhancing academic literacy among tertiary learners: A Malaysian experience. 3L: Language, Linguistics, Literature ${ }^{\circledR}$. 2007; 13: 1-21.

[10] Musa NC, Lie KY, Azman H. Exploring English language learning and teaching in Malaysia. GEMA Online ${ }^{\circledR}$ Journal of Language Studies. 2012; 12(1): 271-282.

[11] Javed M, Eng, LS, Mohamed, AR. Developing reading comprehension modules to facilitate reading comprehension among Malaysian secondary school ESL students. International Journal of Instruction. 2015; 8(2): 139-154.

[12] Mohamed AR, Lin SE. READS: Reading evaluation and decoding system in support of informed reading instruction. Journal of Research \& Reflections in Education. 2010; 4(2): 126-141.

[13] Mohamed, AR, Lin, SE, Mohamed Ismail, SA, M. Making sense of reading scores with Reading Evaluation and Decoding System (READS). English Language Teaching. 2010; 3(3): 35-46.

[14] Mohamed AR, Lin SE, Mohamed Ismail SA. The potency of 'READS' to inform students' Reading Ability. RELC Journal. 2012; 43(2): 271-82.

[15] Malaysia Department of Statistics. Report of Household Income and Basic Amenities Survey. 2016. Available from: https://www.dosm.gov.my/v1/index.php?r=column/cthemeByCat\&cat=120\&bul_id=RUZ5REwveU1ra1hGL21JWVl PRmU2Zz09\&menu_id=amVoWU54UT10a21NWmdhMjFMMWcyZz09 [Accessed 18th May 2020].

[16] Idrus, H., Salleh, R. Perceived self - efficacy of Malaysian ESL engineering and technology students on their speaking ability and its pedagogical implications. The English Teacher. 2017; 15: 61-75.

[17] Azmimurad AM, Osman N. Analysis of technical vocabulary size among Engineering undegraduates based on year of study and English proficiency level at Universiti Malaysia Pahang. International Journal of Innovative Research and Creative Technology. 2019; 4(4): 96-102. 